Revista Aspas

ppgac - USP

Artigo

\title{
O TEATRO E A GAMBIARRA: ASPECTOS CONTEMPORÂNEOS
}

\section{THE THEATER AND THE GAMBIARRA: CONTEMPORARY ASPECTS}

\section{EL TEATRO Y LA GAMBIARRA: ASPECTOS CONTEMPORÁNEOS}

\section{Assis Benevenuto}

Assis Benevenuto

UFMG; Doutorando; Pesquisa em andamento (2020-2024). Área de estudo: literaturas modernas e contemporâneas. Linha de pesquisa: literatura, outras artes e mídias. Orientadora: Sara Rojo. Atuação profissional: Ator, dramaturgo, diretor, editor de teatro pela Editora Javali. Integrante do Grupo Quatroloscinco Teatro do Comum. E-mail: assisvidigal@gmail.com 


\section{Resumo}

Este texto reflete sobre como o universo da gambiarra (Rodrigo Boufleur) está presente no fazer teatral contemporâneo. Para tanto, traça-se a relação existente entre o teatro e o início da modernidade, as transformações ocorridas pela inserção do mercado a partir do choque entre o Velho e Novo Mundo. Davi Kopenawa, Ailton Krenak e Sérgio de Carvalho fundamentam essa perspectiva. As criações cênicas do grupo mineiro Quatroloscinco Teatro do Comum atestam o corpus teórico, demonstrando cenográfica e dramaturgicamente aspectos visíveis da gambiarra.

Palavras-chave: capitalismo, cenografia, dramaturgia, mercado, táticas

\section{Abstract}

This text reflects on how the universe of gambiarra (Rodrigo Boufleur) is present in contemporary theatrical work. For this purpose, the relationship between the theater and the beginning of modernity is traced, the transformations occurred by the insertion of the market from the clash between the Old and New World. Davi Kopenawa, Ailton Krenak and Sérgio de Carvalho support this perspective. The scenic creations of the mineiro group Quatroloscinco Teatro do Comum attest to the theoretical corpus, demonstrating scenographically and dramaturgically visible aspects of the gambiarra.

Keywords: capitalism, dramaturgy, market, scenography, tactics

\section{Resumen}

Este texto reflexiona sobre cómo el universo de gambiarra (Rodrigo Boufleur) está presente en la obra teatral contemporánea. Para eso, se traza la relación entre el teatro y el inicio de la modernidad, las transformaciones que se produjeron debido a la inserción del mercado del choque entre el Viejo y el Nuevo Mundo. Davi Kopenawa, Ailton Krenak y Sérgio de Carvalho apoyan esta perspectiva. Las creaciones escénicas del grupo minero Quatroloscinco Teatro do Comum dan fe del corpus teórico, demostrando aspectos escenográfica y dramatúrgicamente visibles de la gambiarra.

Palabras-clave: capitalismo, dramaturgia, escenografía, mercado, tácticas 
A partir de três obras do Quatroloscinco Teatro do Comum ${ }^{1}$ - do qual integro como dramaturgo, ator e diretor - propomos uma reflexão sobre alguns modos de produção do teatro contemporâneo em relação à mercadoria e a gambiarra. Sobre esta, usaremos a perspectiva de Rodrigo Boufleur (2013): "uma forma de improvisação a partir de recursos disponíveis, provenientes da produção industrial, visando um propósito utilitário". A gambiarra "se realiza a partir de uma realidade de consumo". A teorias de Michel de Certeau e de Karl Marx fundamentam a tese de Boufleur.

\title{
Mercadoria
}

A relação entre sociedade e mercadoria pode parecer indissociável para muitos de nós hoje em dia. Sobre tal condição, o líder yanomami Davi Kopenawa aponta:

\begin{abstract}
Mas os brancos são gente diferente de nós. Devem se achar muito espertos porque sabem fabricar multidões de coisas sem parar. [...] Seu pensamento está concentrado em seus objetos o tempo todo. Não param de fabricar e sempre querem coisas novas. [...] Temo que sua excitação pela mercadoria não tenha fim e eles acabem enredados nela até o caos. (KOPENAWA; ALBERT, 2015, p. 418)
\end{abstract}

Em seu livro, Kopenawa narra a experiência da primeira vez que visitou uma cidade: "aqueles amontoados de mercadorias empoeiradas me deixavam confuso. [...] Só bem mais tarde entendi que os brancos tratam suas mercadorias como se fossem mulheres por quem estão apaixonados" (idem, p. 419). O choque narrado por Kopenawa transporta nossa imaginação a um tempo mais remoto: a chegada dos europeus por estas terras.

Aquele navio que chegou na praia, ele trazia alguns homens que portavam espadas e alguns homens que portavam uma espada que em vez de ser empunhada pelo cabo, era empunhada pela lâmina, que eles chamavam de cruz. Muito significantemente a espada dos soldados e a cruz dos santos que vieram nos navios com eles, elas têm o mesmo desenho. [...] E para o meu povo [...] sempre foi muito difícil estabelecer uma diferença entre o que porta a cruz e o que porta a espada. (KRENAK, 2015, p. 155)

\footnotetext{
${ }^{1}$ www.quatroloscinco.com
} 
Os povos originários conheciam o sentido de guerrear, da economia, da memória, da crença etc.; porém não sabiam a razão que fomentava a conexão entre a cruz e a espada daqueles que invadiram estas terras, como evidenciou Krenak. Desconheciam a coerção bélica da pólvora, assim como a imposição da lógica de mercado capitalista e suas incontáveis mercadorias. Genocídio, roubo de terra, ouro, diamante, minério, escravização, tudo objetivou a produção de riqueza para a acumulação de capital que, sustentando séculos de colonização, culminou nas revoluções industriais, independências tardias dos países, guerras mundiais, o contemporâneo. Aquele Deus que cooptou o "ser" dos que aqui viviam, tornou-se a religião do "ter". A transformação econômica, religiosa e filosófica em curso no Velho Mundo encontrou nas colônias o substrato ideal para vigorar. Walter Benjamin, dentre outros pensadores, descortinou a relação parasitária entre capitalismo e religião no Ocidente:

Nisto reside o aspecto historicamente inaudito do capitalismo: a religião não é mais forma do ser, mas seu esfacelamento. Ela é a expansão do desespero ao estado religioso universal, do qual se esperaria a salvação. A transcendência de Deus ruiu. Mas ele não está morto; ele foi incluído no destino humano. Essa passagem do planeta "ser humano" pela casa do desespero na solidão absoluta de sua órbita constitui o éthos definido por Nietzsche. Esse ser humano é o ser super-humano [Übermensch], o primeiro que começa a cumprir conscientemente a religião capitalista. (BENJANMIN, 2013, p. 21-22)

Pensar criticamente sobre o mundo da mercadoria, sendo filhos e nos alimentando dele, é uma tarefa complexa. Hoje, como imaginar a humanidade vivendo sem dinheiro e mercadoria? A primeira imagem que o sistema ardilosamente nos impõe é de miséria, situação sub-humana. É neste panorama, dentre as infindas estratégias de sobrevivência e adaptação, que surge a gambiarra, segundo Boufleur, como ação subproduto da condição industrial visando um reequilíbrio entre o (material) disponível e o demandado. Táticas de resistência frente à configuração humana no mundo da mercadoria. Sobre tal condição humana, o líder yanomami Davi Kopenawa nos alerta: "Os humanos adoecem, envelhecem e morrem com facilidade. Já o metal dos facões, dos machados e das facas fica coberto de ferrugem e sujeira de 
cupim, mas não desaparece tão depressa! Assim é. As mercadorias não morrem." (KOPENAWA; ALBERT 2015, p. 409)

\section{Teatralidades e o Teatro}

É sabido que diversas teatralidades já faziam parte dos rituais dos povos originários. Mas o conceito ocidental de "teatro" aportou nesta terra através dos europeus. O pesquisador Sérgio de Carvalho (USP) apresenta, no artigo "A teatralidade fora do lugar: a cena tupinambá no triunfo de Rouen", importantes e curiosas informações sobre o teatro e formas de teatralidade praticadas pelos europeus a partir do processo de colonização; e como a transição dos modelos de economia, governos e religião estão intimamente relacionados aos problemas da representação. Carvalho pesquisou documentos que registram o Triunfo (procissão espetacular originada nos ritos gregos aos deuses) realizado em homenagem ao Rei Henrique II, na cidade francesa de Rouen, no ano de 1550, onde dezenas de índios tupinambás foram levados da costa brasileira para tão distante para "representarem" a si mesmos.

[...] é possível dizer que a teatralidade processional das entradas triunfais foi contemporânea da fusão simbólica entre o poder religioso e o poder monárquico, sendo também devedora do crescimento dos mercados burgueses, havendo grande interação desses agentes no que se refere ao seu sentido formal e intenções alegóricas, que se encaminharam para hibridismos cada vez mais curiosos, capazes de misturar imaginário mitológico da Antiguidade, colecionismo do Novo Mundo, figurações do catolicismo em luta, humanismo neoplatônico e tecnologia mercantil. (CARVALHO, 2017, p. 196)

O teatro foi incorporado à mercadoria como um exercício de autoafirmação pelo poder político, econômico e religioso. Carvalho afirma que antes mesmo da hegemonia do palco italiano e do drama burguês, o teatro elisabetano e o do século de ouro espanhol "conheceria a indiviaduação como problema trágico" (idem, p. 233). Sobre este processo estético e político colocado em desenvolvimento no novo mundo:

As vozes contrárias aos processos do capital em breve não teriam mais existência social, e o elemento diabólico (e também o dialógico) se tornariam abstratos ou proscritos, conforme se 
extinguia o escambo e o escravismo se desenvolvia numa economia de exportação. A figuração da individualidade não surgiria em cena sequer como problema, porque o outro estava ausente. (idem, p. 234)

Restou a ilusão de se poder alcançar alguma liberdade e autonomia do Ser. Para o pesquisador, nem mesmo os homens das letras daquela época conseguiram suspeitar o que estaria por vir pois, "a melancolia diante de uma Razão irrealizável não os deixava ver que o atraso local correspondia ao avanço do capitalismo global” (idem, p. 234).

\section{Teatro e suas gambiarrices}

Percebemos uma tendência de os edifícios teatrais serem deslocados para dentro de grandes centros comerciais, como ocorreu com os cinemas. As produções teatrais vêm sendo incorporadas na lógica da vitrine: onerosos musicais da Broadway e os espetáculos protagonizados por atores da televisão são as bilheterias mais rentáveis. Já outros modos teatrais vêm lutando pela sua existência. Obras que geralmente carregam um enorme potencial político e social, e se diferenciam nas condições de produção e de consumo das grandes produções, por vezes carecem de patrocinadores. Vimos que a arte convivial em meio a uma pandemia é uma arte proibida, diferente da música que continuou nas plataformas; da literatura nos livros, das fotografias e quadros nas telas (ainda que digitais), do cinema pela internet e televisão. $O$ enfraquecimento das políticas públicas promovido pelo governo atual tem provocado o sucateamento ascendente da cadeia produtiva do teatro, fazendo com que a lógica da mercadoria se acirre sobre essa arte.

"Gambiarrice" não é em si uma gambiarra (Boufleur), mas sugere um modo de fazer característico de muitas práticas teatrais. Seja pelas condições financeiras precárias em que muitos edifícios teatrais se encontram, tal como coletivos e grupos. O mais intuitivo seria pensarmos que a gambiarra está nas traquitanas realizadas no universo teatral - momentos de urgência e falta de material específico nas apresentações, nos reparos, situações em que o improviso técnico é necessário na iluminação, cenário, figurino etc. E, sim, 
está! Também nas fitas crepes, fitas Hellerman (abraçadeiras), os tocos de madeira, sacos de areia (peso), cordas, fios, nylon etc., que muitas vezes permitem a realização de uma peça. No Teatro de Bonecos e de Objetos, que são confeccionados a partir de uma ampla gama de materiais. Nas parafernálias improvisadas que dão vida ao Teatro de Rua, originado dos Triunfos, do Teatro Medieval, feiras populares, circo etc. Nas manifestações teatrais populares e as pernas de pau, feitas de pedaços de madeira ou até mesmo latas amarradas com pedaços de borracha de pneu; figurinos coloridos costurados com retalhos de pano; reutilização dos mais variados materiais para a construção visual dos cortejos. Referência sobre o universo da gambiarra, a pesquisadora Sabrina Sedlmayer (UFMG) aponta:

\begin{abstract}
A gambiarra está presente em muitos gestos de criação de linguagem, verbal ou imagética, e roça certo patrimônio vivencial, certos arranjos nos quais a escassez de recursos é operacionalizada e a sobrevivência é alçada via invenção do cotidiano. A hipótese que se lança é que há potentes gestos - práticas, táticas, políticas - que se alicerçam justamente na escassez de produtos, de recursos e/ou serviços. Nesse paradoxo, na transformação do negativo em positivo, percebe-se uma potência singular na qual a falta é transformada. (SEDLMAYER, 2019, sp.)
\end{abstract}

Esta relação entre teatro e gambiarra também poderia ser abordada noutra perspectiva mais filosófica. Se o Teatro é o lugar onde a vida humana é representada, mas se a vida humana se tornou mercadoria, então, a representação do Ser, hoje, não se trataria de uma tentativa de reelaboração humana, na busca por um reequilíbrio entre o disponível (o humano subproduto do capitalismo) e o demandado (utopia do Ser em liberdade)? Os corpos humanos não seriam marionetes-gambiarras em cena? Este ponto de vista nos leva a outra direção devido a sua complexidade, deixaremos para refletir noutro momento.

\title{
Grupo Quatroloscinco Teatro do Comum e a gambiarra
}

Formado no ano de 2007 por integrantes egressos da UFMG, o coletivo mantém trabalho continuado de pesquisa e prática artística pautado na 
criação coletiva e na dramaturgia autoral. Importante representante do teatro mineiro contemporâneo, já se apresentou em mais de 70 cidades, em 20 estados brasileiros, além de festivais na Argentina, Cuba e Uruguai. Os exemplos selecionados certificam como o universo da gambiarra está visivelmente presente nas criações do grupo. Situações em que objetos provenientes da economia produtiva humana ganharam um outro uso, a partir de um encontro espontâneo com o material que engendrou um processo criativo, adequando-se a uma demanda real da peça - construção de cenário, sentido, recurso financeiro etc. A "gambiarrice" como sinônimo de potência criativa e que ainda promoveu um "reequilíbrio entre o disponível e o demandado" (Boufleur). Importante frisar que tais obras não receberam nenhum aporte econômico de leis de incentivo, condição determinante da relação entre a gambiarra, o cenário e a dramaturgia.

\section{Espetáculo Outro Lado (2011)}

Figura 1 - Cena "invasão"

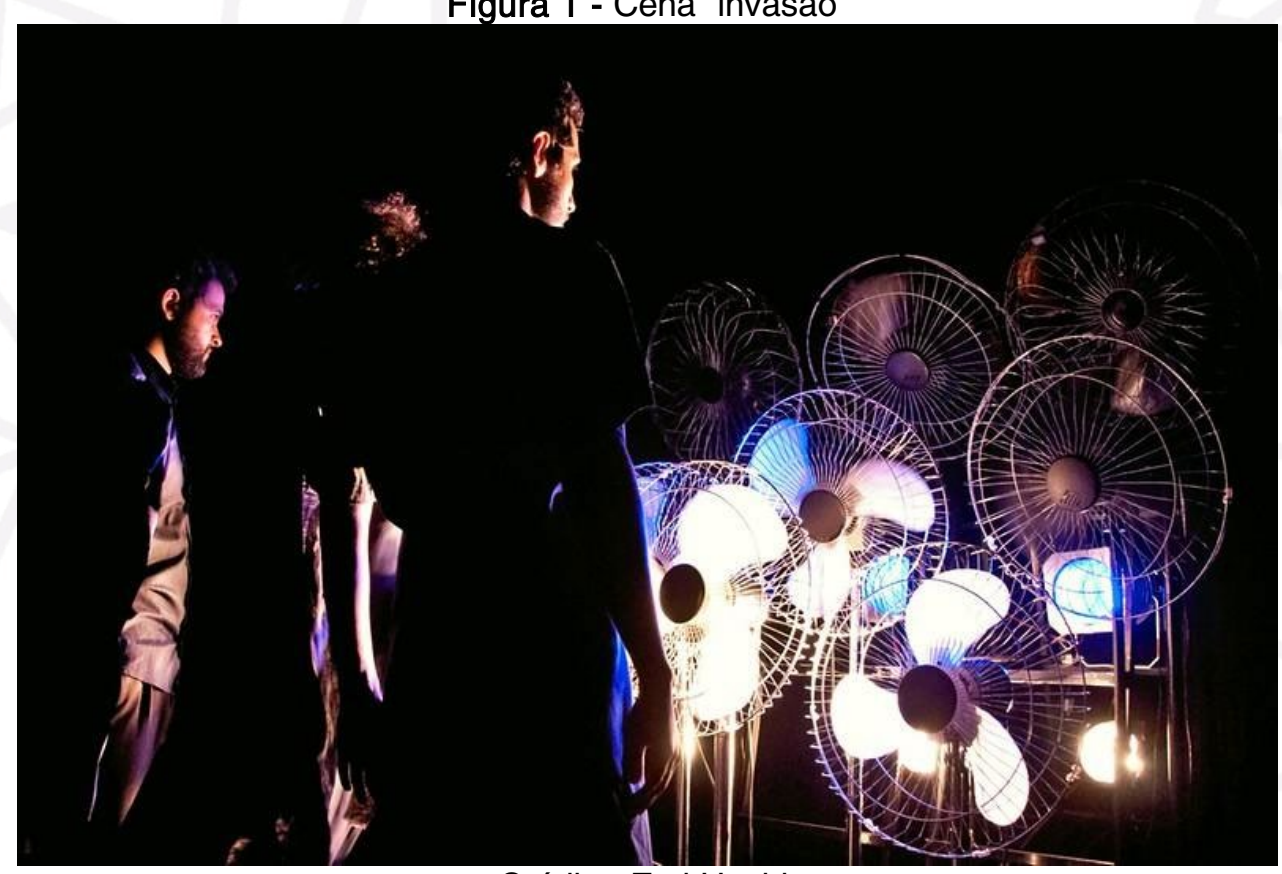

Crédito: Emi Hoshi.

Quando começamos a criar Outro Lado, o grupo ensaiava em uma sala desocupada de uma empresa de serviços. Por lá, encontramos dezenas de ventiladores no "lixo". Definitivamente não poderiam descartados pois eram patrimônio da empresa. Apesar de passíveis de conserto, os modelos eram 
ultrapassados, barulhentos e ocupavam muito espaço, portanto viraram entulho. Do lixo à cena! O enredo de Outro lado é distópico, pandêmico, algo de guerra e estado de sítio. Em cena, os ventiladores de pé não cumprem seu design/destino de mercadoria (ventilar o ambiente), mas compõem imagens dramatúrgicas. A parafernália barulhenta de ferro, metal e fios faz alusão aos destroços da guerra, às hélices dos aviões de ataque, aos invasores e tem a função de dissipar fumaça usada em momentos de tensão dramática, explicitando de forma distanciada o efeito cênico. Além de uma adaptação de caráter econômico relacionada ao processo criativo, o universo das gambiarras se faz presente, pois elas "implicam na subversão dos aspectos de design dos produtos industrializados, especialmente em relação às propriedades de forma e função" (BOUFLEUR, 2013, p 239).

\section{Get Out (2013)}

Get Outé um solo que aborda a capacidade dos pensamentos tornaremse mais concretos do que o "real". Um homem está prestes a embarcar em um voo, mas ele se recusa após imaginar a possível queda do avião.

Figura 2 - Cena "aeroporto"

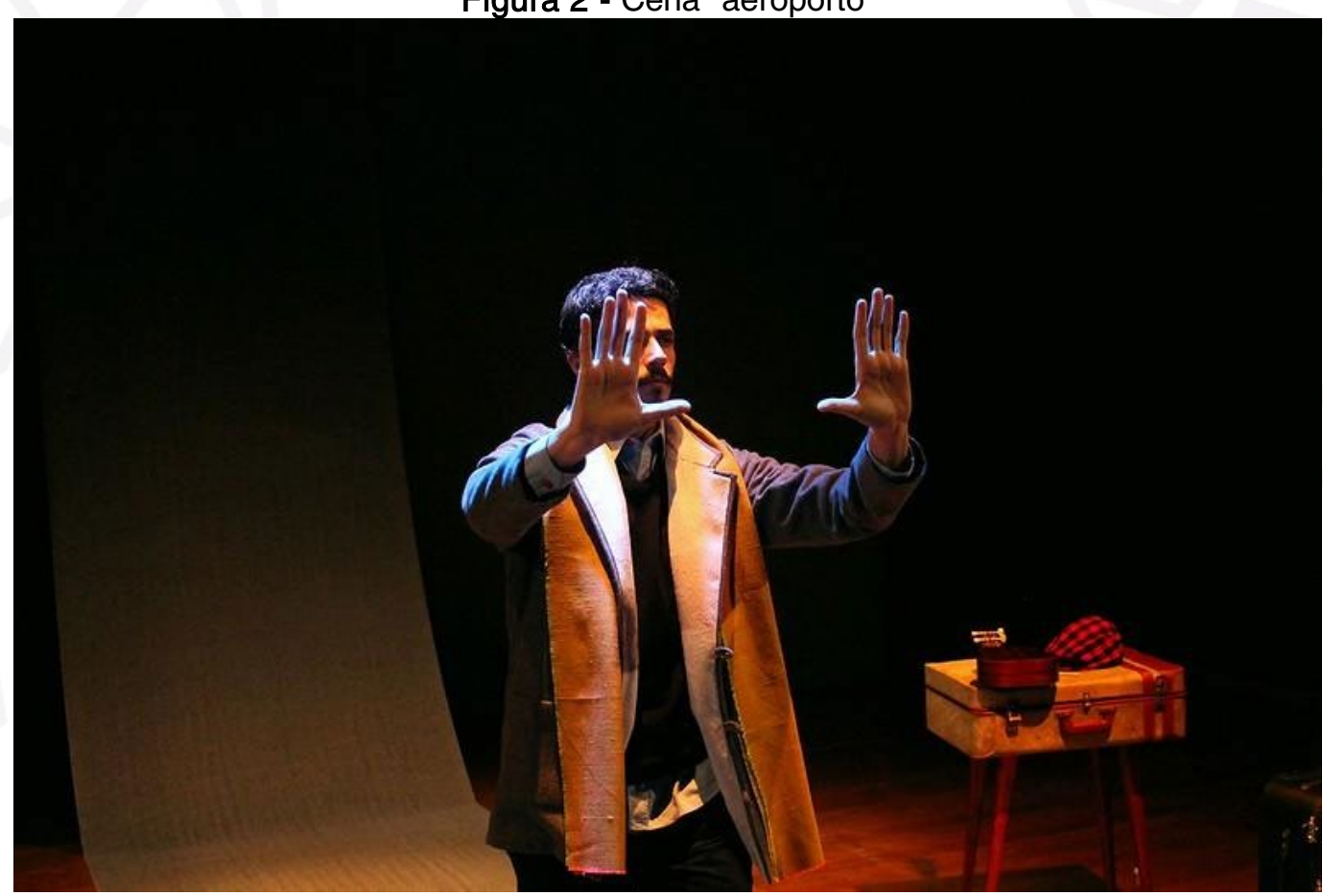

Crédito: Renato Fosseti. 
$\mathrm{Na}$ figura 2, interessa-nos aquela maleta antiga, transformada em mesa, sobre quatro pés palito. No início de 2013, saindo de casa para despachar o lixo, deparei com uma mala ao lado de outras caixas destinadas ao descarte. O estilo antigo despertou minha atenção, ela é confeccionada em couro e compensado fino. Estava muito gasta e não serviria mais como valise de viagens. Porém, o interesse nela foi outro. Durante o processo de criação já havia ficado claro que o personagem não portaria uma mala, seria óbvio para uma situação de aeroporto. A solução foi convertê-la num suporte (mesa) de onde o ator retira alguns elementos que o fazem transitar entre os demais personagens da obra. A mesa-mala concretiza a metáfora, cara ao monólogo, sobre a dicotomia entre ser e parecer ser.

\section{Ignorância (2015)}

Neste derradeiro exemplo, entendemos a gambiarra como um elemento dramatúrgico, que engendra a ação e desnovela questões filosóficas acerca do estatuto da Arte, do universo comum e do capitalismo.

Figura 3 - Cena "galeria de arte"

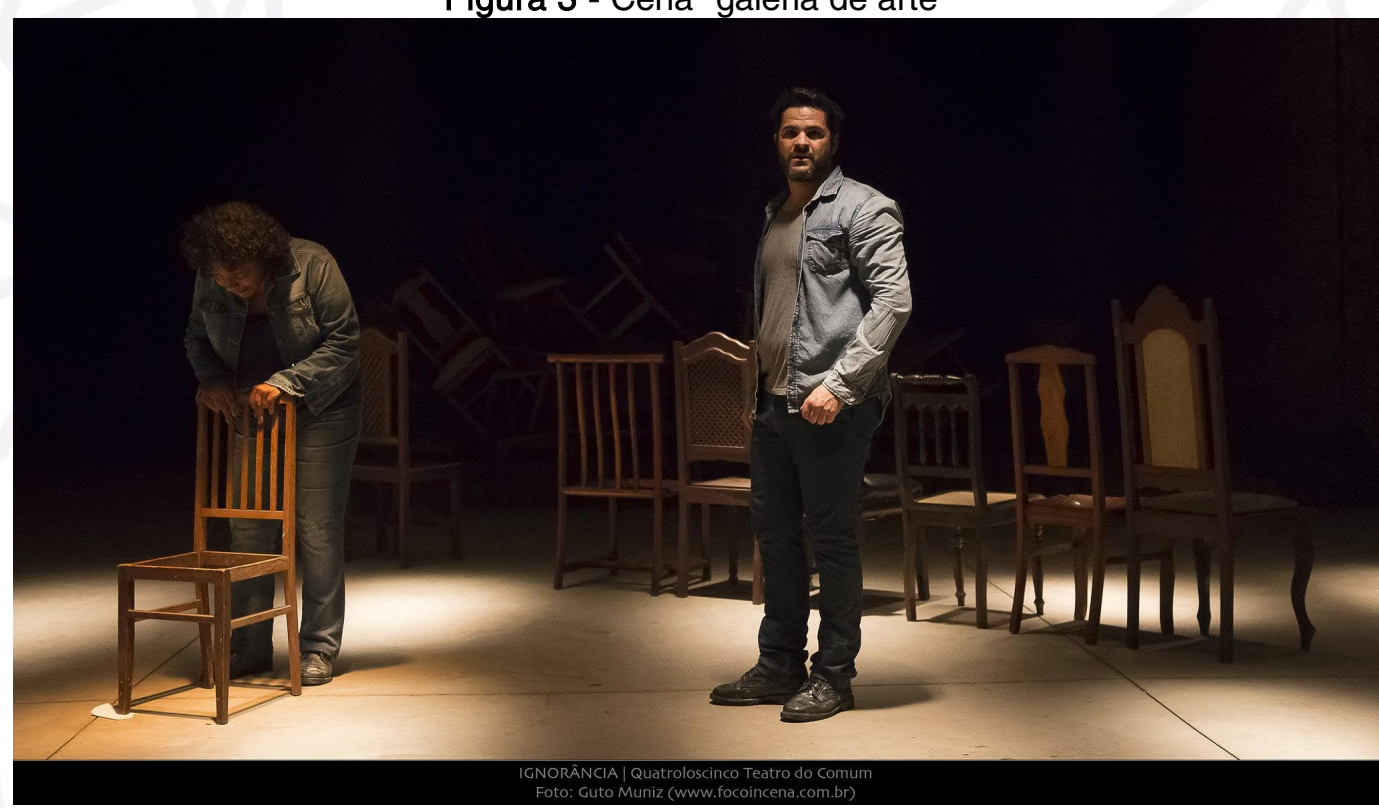

Crédito: Guto Muniz

Há, no canto inferior esquerdo da figura 3, um dos pés da cadeira que está apoiado sobre um objeto branco. Se algo tão comum como calçar o pé 
de uma cadeira pode ser considerado por Boufleur como um perfeito exemplo de gambiarra, o mesmo mecanismo elevado à condição de Arte adquire outros contornos. O contexto desta cena é o encontro corriqueiro entre duas pessoas desconhecidas numa galeria de arte contemporânea. Ela, artista, é frequentadora assídua. Ele, eletricista, está ali pela primeira vez.

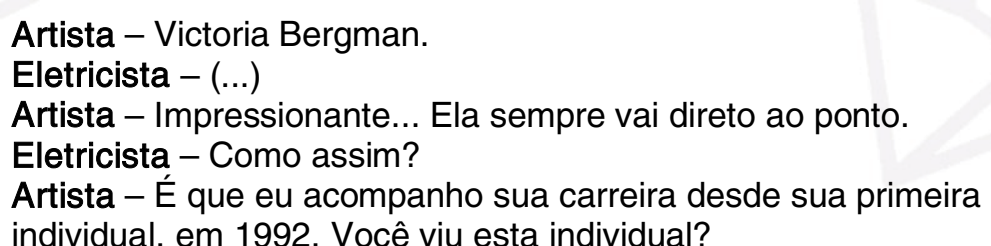
Eletricista - Não...

Artista - Excelente. Muito impactante [...] é magnifico, é fantástico como ela consegue manipular objetos simples do cotidiano, retirálos de seus lugares e transformá-los em algo irreconhecível. É a evocação poética do potencial da arte e sua capacidade de agir e intervir na realidade concreta. É como um vazio que se torna tangível na sua própria ausência. Parece algo trivial, mas em um contexto de total tensão simbólica. Uma abstração platônica friccionada.

Eletricista - Abstração pla... pla, eu não...

Artista - Você reparou que aquele é o único pé que não está encostado no chão diretamente?

Eletricista - É. Tem um vidro aí embaixo.

Artista - Então... é isso.

Eletricista - Isso o quê?

Artista - A fissura, o detonador! O detalhe que desestrutura toda uma convenção estética e cultural. Como se a obra denunciasse que um mundo totalmente coerente não existe. Expressividade, perspectiva e subversão tudo concentrado num só ponto. Pura dialética.

Ele começa a ir embora.

Artista - Me desculpe, eu não queria te chatear! (BENEVENUTO; COLLETA, 2016 p. 30-31)

Como que um gesto tão comum, algo sem nenhum valor comercial, seria capaz de gerar tanto impacto em uma galeria de arte contemporânea? A Artista afirma que aquela obra desestrutura toda uma convenção estética e cultural. Em parte, esta é uma condição da gambiarra como propõe Boufleur, a diferença é que, para o autor, a gambiarra tem um propósito utilitário. $\mathrm{Na}$ galeria de arte ela estaria desterritorializada, destituída do seu valor de uso.

\footnotetext{
Artista - Você faz o quê?

Eletricista - Sou eletricista.

Artista - Ah.

Eletricista - Trabalho com cabos de energia, fios de alta tensão, 110V, 220V...
} 
Artista - Sim, eu sei o que um eletricista faz

Eletricista - Trifásico... E você?

Artista - Eu sou artista.

Eletricista - Artista? Ó...

Artista - É. Também sou escritora, fotógrafa, ativista...

Eletricista - Ativista?

Artista - Sim. Eu me envolvo em causas coletivas, políticas, sociais...

Eletricista - Sindicalista, né?

Artista - Não, não. Outra coisa! Mas eu fico muito feliz em ver você aqui.

Eletricista - Eu? Mas a senhora nem me conhece.

Artista - Não você, exatamente, mas gente como você. (Para o público) É muito bom, é muito bom quando um lugar como esse, tão específico, para alguns até elitista, coisa que eu não concordo, não mesmo, recebe a visita de pessoas assim, como você, simples, ordinárias, que nada tem a ver com a arte. É neste momento que este lugar mostra sua missão, a sua funcionalidade, afinal, para que serve a arte senão para interferir diretamente na vida das pessoas comuns, não é? (idem, p. 33-34)

Podemos observar uma curiosa inversão: a galeria de arte sendo um lugar "tão específico e elitista", expondo uma simples gambiarra. Ao mesmo tempo em que somente uma pessoa tão comum, o eletricista, é quem pode realizar a missão daquele lugar. O objetivo da Arte é intervir na vida de pessoas comuns? Ou será que o universo das pessoas comuns, incorporada pelo mercado, passou a comportar-se com valor de Arte?

Para Boufleur quanto mais o cenário econômico for baixo, mais gambiarras haverão de acontecer, e "as gambiarras, em seu conjunto, podem representar um exemplo silencioso de resistência à ordem industrialcapitalista estabelecida" (BOUFLEUR, 2013, p. 239). Então, se a gambiarra é deslocada para o campo da arte, ela ainda cumpriria sua função de resistência? Na cena, o eletricista conta que também é pintor e pergunta à artista como que faz para expor suas obras no museu.

\footnotetext{
Artista - Ô, meu querido... isso é uma galeria de arte contemporânea. Para expor aqui tem que ser um artista importante, de renome internacional. Você tem ideia de quanto custa essa obra? Quase meio milhão.

Eletricista - Nessa cadeira?

Artista - Isso não é uma cadeira. (BENEVENUTO; COLETTA, 2016, p 37)
}

Se a arte foi incorporada pela mercadoria, toda mercadoria tem potencial para ser arte? Eis o abismo anunciado por Baudelaire, no século XIX. Segundo 
Giorgio Agamben, "a grandeza de Baudelaire diante da intromissão da mercadoria residiu no fato de ter respondido a essa intromissão, transformando em mercadoria e em fetiche a própria obra de arte" (AGAMBEN, 2007, p. 75). Desde então, a "polêmica utilitarista da obra de arte" refletiu em diversas provocações ao logo da história, tal como em Duchamp (1917), que expôs o famoso mictório (objeto produzido em escala industrial) com sua assinatura. Se a gambiarra é um subproduto do capitalismo, "constitui um trabalho complementar, mas que não representa valor econômico" (BOUFLEUR, 2013, p. 238), o estatuto da Arte discutido na cena de Ignorância está em sentido oposto ao da gambiarra. Nem mesmo o subproduto da mercadoria escapa ao fetiche do mercado. A galeria expõe objetos ordinários (retirados) da vida das pessoas comuns e tem por objetivo levar (devolver) arte àquelas mesmas pessoas, que jamais terão poder econômico para adquiri-las. Não estaria intimamente relacionado a este panorama uma série de reivindicações atuais sobre os limites de representação da e na arte? Por exemplo, no direito de reconhecimento social e político de lugares de fala, contra a prática cultural que trata toda e qualquer representação como produto? O Eletricista, um gambiarrista original, problematiza os limites da arte contemporânea. O desfecho da cena revela a incompatibilidade de mundos (político e social) das personagens e acirra a polêmica filosófica.

Eletricista - A senhora vai me desculpar, mas isso aqui é uma cadeira.

Artista - Não, não é.

Eletricista - Só pode ter ficado doida...

Artista - (...)

(Ele rodeia a cadeira e se senta nela)

Artista - Não, isso é crime!

Eletricista - Não, é uma cadeira...

Artista - Isso é crime! Socorro! Seguranças! Seguranças! Socorro! Eletricista - Não precisa disso, senhora. Eu só queria te mostrar que isso aqui é uma...

Artista - Você não entende... não entende... Você não sabe diferenciar significado de significante, obra de objeto. Você não sabe o que é reprodução, mimeses, mediação simbólica. Arte não é matéria, arte é conceito e isso você nunca vai entender. E se você não consegue compreender isso, melhor seria que nem tivesse entrado aqui, nesse lugar. Você jamais será um artista... jamais. Artistas são pessoas diferenciadas, brilhantes, iluminadas, inteligentes... e você jamais será um. E se você não sair daqui agora, eu vou fazer um escândalo. Eu vou dizer que você queria roubar esta obra. Pior, vou dizer que você tentou me obrigar a 
sentar nesta obra para abusar sexualmente de mim em cima dela. (BENEVENUTO; COLLETA, 2016 p. 38-39)

É o "curto-circuito" de nossa sociedade, tal como alertou Kopenawa: "temo que sua excitação pela mercadoria não tenha fim e eles acabem enredados nela até o caos". O descontrole patético da Artista que simula uma relação sexual com a obra - não com a cadeira - até o limite do constrangimento é o Triunfo do fetiche da arte elevada à condição de mercadoria sobre o humano. Segundo Agamben:

Baudelaire compreendeu que, se a arte quisesse sobreviver na civilização industrial, o artista deveria procurar produzir na sua obra a destruição do valor de uso e da inteligibilidade tradicional, que estava na raiz da experiência do choc, desta maneira, ele teria conseguido fazer da obra o próprio veículo do inapreensível e restaurar na própria inapreensibilidade um novo valor e uma nova autoridade. (AGAMBEN, 2007, p. 75-76)

O problema teórico mostra-se também ético e político. Atravessa as relações humanas por meio das relações econômicas e do poder que o regime de visibilidade da arte adquiriu na sociedade capitalista contemporânea. $\mathrm{Na}$ galeria de arte, a cadeira com calço de vidro definitivamente não é uma gambiarra pois, segundo Boufleur, não deve representar valor econômico, e deve promover um reequilíbrio entre o disponível e o demandado.

Figura 4 - Cena final "galeria"

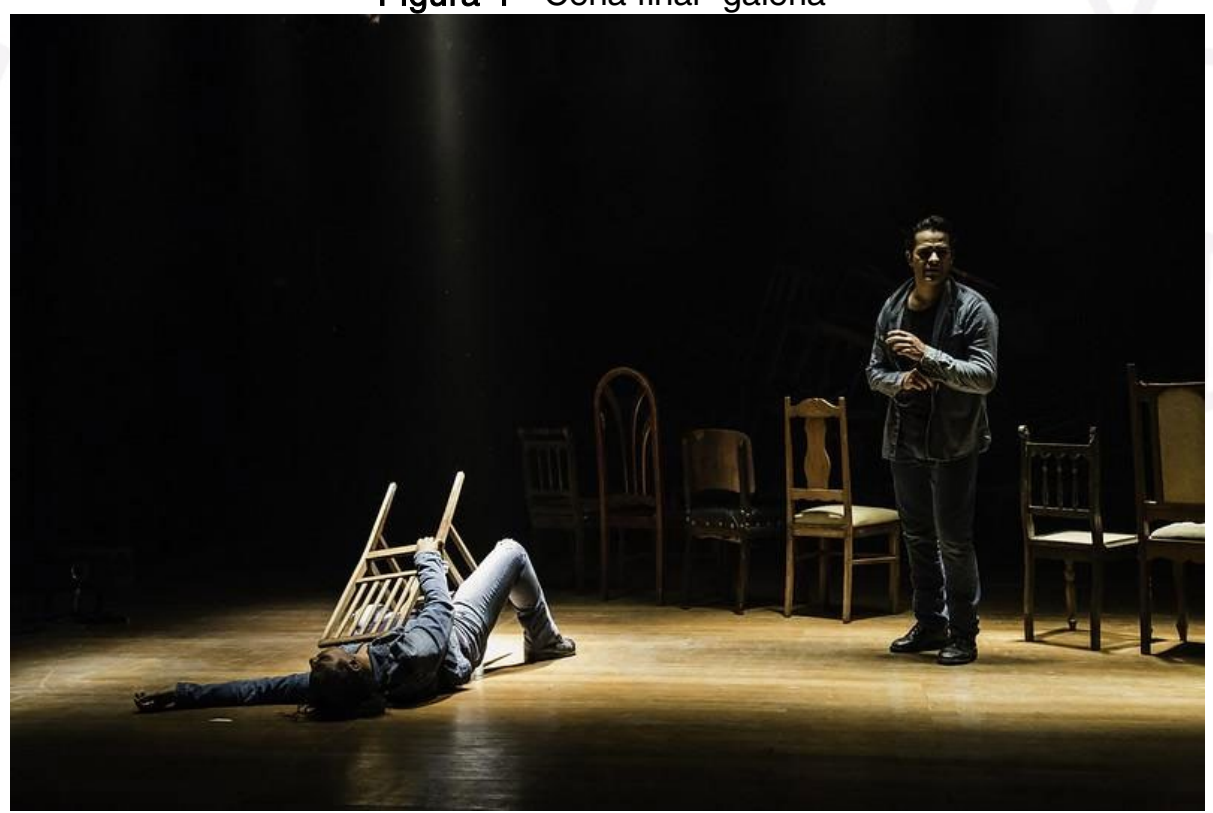

Crédito: Letícia Souza 
Estes três exemplos apontam relações entre a mercadoria, a gambiarra e o teatro - desenvolvidas enquanto cenografia e dramaturgia do grupo Quatroloscinco - que elucidam estratégias críticas e de criação em um contexto socioeconômico contemporâneo. Aspectos que podem ser amplamente reconhecidos em demais produções teatrais no país. A semente do teatro, geralmente despertada em atividades escolares, cursos livres, nas brincadeiras da infância, etc., opera nessa mesma técnica de improviso e recriação a partir de elementos disponíveis. O teatro trabalha com essa potência de transformação que, por vezes, está reduzida a poucos itens: a língua e o corpo. Nesse mecanismo lúdico, há uma diferença a ser observada quando o teatro integra o mercado, torna-se meio econômico, profissão. Atentemo-nos, o universo da gambiarra delineado por Boufleur e Sedlmayer, entre outros, pode ser em uma profícua estratégia de resistência - assim como as perspectivas de Krenak e Kopenawa -, capaz de produzir objetos e reflexões importantes que, dentre tantas funções, iluminam o caminho sombrio de sucateamento sociocultural e humano vivenciado no país.

\section{Bibliografia}

AGAMBEN, Giorgio. Estâncias - a palavra e o fantasma na cultura ocidental. Tradução de Selvino José Assmann. Belo Horizonte: Editora UFMG, 2007. BENEVENUTO, Assis. COLETTA, Marcos. Ignorância. Belo Horizonte: Editora Javali, 2016.

BENJAMIN, Walter. O capitalismo como religião. Organização Michel Löwy. Tradução Nélio Schneider e Renato Ribeiro Pompeu. 1a ed. - São Paulo: Boitempo, 2013

BOUFLEUR, Rodrigo. Fundamentos da gambiarra: a improvisação utilitária contemporânea e seu contexto socioeconômico. Tese. FAU-USP. Paulo, 2013. Online. Acesso em: 23 fev. 2021. Disponível em: https://www.teses.usp.br/teses/disponiveis/16/16133/tde-02072013-134355/ptbr.php 
CARVALHO, S. A teatralidade fora de lugar: a cena Tupinambá no triunfo de Rouen. Sala Preta, [S. I.], v. 17, n. 2, p. 192-235, 2017. DOI: 10.11606/issn.22383867.v17i2p192-235. Disponível em:

https://www.revistas.usp.br/salapreta/article/view/140221. Acesso em: 19 mar. 2021.

KOPENAWA, Davi; ALBERT, Bruce. A queda do céu: as palavras de um xamã yanomami. Tradução Beatriz Perrone-Moisés; prefácio de Eduardo Viveiros de Castro - 1ee. - São Paulo: Companhia das Letras, 2015.

KRENAK, Ailton. Encontros Ailton Krenak. Organização Sergio Cohn. 1를. - Rio de Janeiro: Azougue, 2015.

SEDLMAYER, Sabrina. Ataque especulativo ou a gambiarra versus o tosco brasileiro. Arte!Brasileiros. 24/06/2019. Disponível em:

https://artebrasileiros.com.br/arte/artigo/ataque-especulativo-ou-a-gambiarraversus-o-tosco-brasileiro/ Acesso em: 15 out. 2021. 